American Journal of Applied Sciences 8 (9): 860-863, 2011

ISSN 1546-9239

(C) 2011 Science Publications

\title{
Effect of Verapamil on Serum Level of Salinomycin in Diabetic Rats
}

\author{
${ }^{1}$ Hossein Najafzadeh, ${ }^{1}$ Said Reza Fatemi and ${ }^{2}$ Amir Ashna \\ ${ }^{1}$ Faculty of Veterinary Medicine, Shahid Chamran University, Ahvaz, Iran \\ ${ }^{2}$ Department of Veterinary Medicine, Faculty of Veterinary Medicine, \\ Shahid Chamran University, Ahvaz, Iran
}

\begin{abstract}
Problem statement: The aim of present study was evaluation function of P-glycoprotein with or without verapamil in normal and diabetic rats; which the function of P-glycoprotein was indirectly evaluated by detection of serum slainomycin concentration with HPLC method. Approach: This study was carried in 4 groups of rats including normal rats which received salinomycin and verapamil together salinomycin; and diabetic rats which received salinomycin and verapamil together salinomycin. Serum concentration of salinomycin was measured by HPLC after $3 \mathrm{~h}$ from its administration. Results: Results show the serum concentration of salinomycin significantly elevated in diabetic rats which received verapamil together salinomycin; while this concentration did not significantly change in other groups. Conclusion: Since the p-glycoprotein activity decreases in diabetic conditions and verapamil inhibits it; probably transport of salinomycin from blood to tissues or its elimination was decreased that caused its elevated serum concentration.
\end{abstract}

Key words: Salinomycin significantly, verapamil inhibits, diabetes induction, HPLC method, serum concentration, p-glycoprotein, diabetic rats, serum level, tumor cells

\section{INTRODUCTION}

P-glycoproteins (P-gp) are transmembrane carrier that prevents the cellular accumulation of some xenobiotics and endogenous compounds and is responsible for certain multidrug resistance mechanism in tumor cells (Aller et al., 2009). P-gp is belonged to ATP-binding cassette transport protein superfamily (ABCB1/MDR1) (De Lange, 2004). This pump is mainly expressed in organs that have an excretion (liver, kidney), absorption (intestine) or barrier function, such as the blood-brain barrier (Mercier et al., 2004; Hsiao et al., 2008). For example, P-gp inhibition at the rat BBB has been determined, when the rat is pretreated with cyclosporine A (as p-gp inhibitor) the brain/plasma ratio of verapamil is increased (Hsiao et al., 2006; Hendrikse and Vaalburg, 2002). Based on these data and others, it has been widely postulated that P-gp plays a vital role in limiting drug distribution at bloodbrain barrier and drug interactions will result in an important increase in brain concentrations of the affected drugs and, therefore, their CNS efficacy or toxicity (Neuhaus et al., 2010).

Salinomycin is a polyether antibiotic belonging to the group of ionophores. Salinomycin is extensively used as a coccidiostat in poultry and other livestock
(Rajaian et al., 2009). Severe human poisoning with salinomycin has also been reported (Story and Doube, 2004). P-gp activity may affect the toxic exposure to salinomycin. Individuals with reduced or absent P-gp activity could therefore be more susceptible to salinomycin toxicity (Lagas et al., 2008). Verapamil, a calcium channel blocker, is substrate and inhibitor of pgp (Sulova et al., 2008).

This study was carried to evaluation function of Pglycoprotein with or without verapamil in normal and diabetic rats; which the function of P-gp was indirectly evaluated by detection of serum slainomycin concentration with HPLC method.

\section{MATERIALS AND METHODS}

This study was carried in 4 groups of rats (10 rats in each group). The male Wistar rats were purchased from laboratory animal center Jundishapour of Ahvaz. The age of rats was 12 weeks. The animals access to food and water ad libitum under $12 \mathrm{~h}$ light and 12 dark conditions. Two groups of normal rats received salinomycin ( $1 \mathrm{mg} \mathrm{kg}^{-1}$ orally) and verapamil $(25 \mathrm{mg}$ $\mathrm{kg}^{-1}$ orally) (Bansal et al., 2009) and $1 \mathrm{~h}$ later salinomycin ( $1 \mathrm{mg} \mathrm{kg}^{-1}$ orally). 
Am. J. Applied Sci., 8 (9): 860-863, 2011

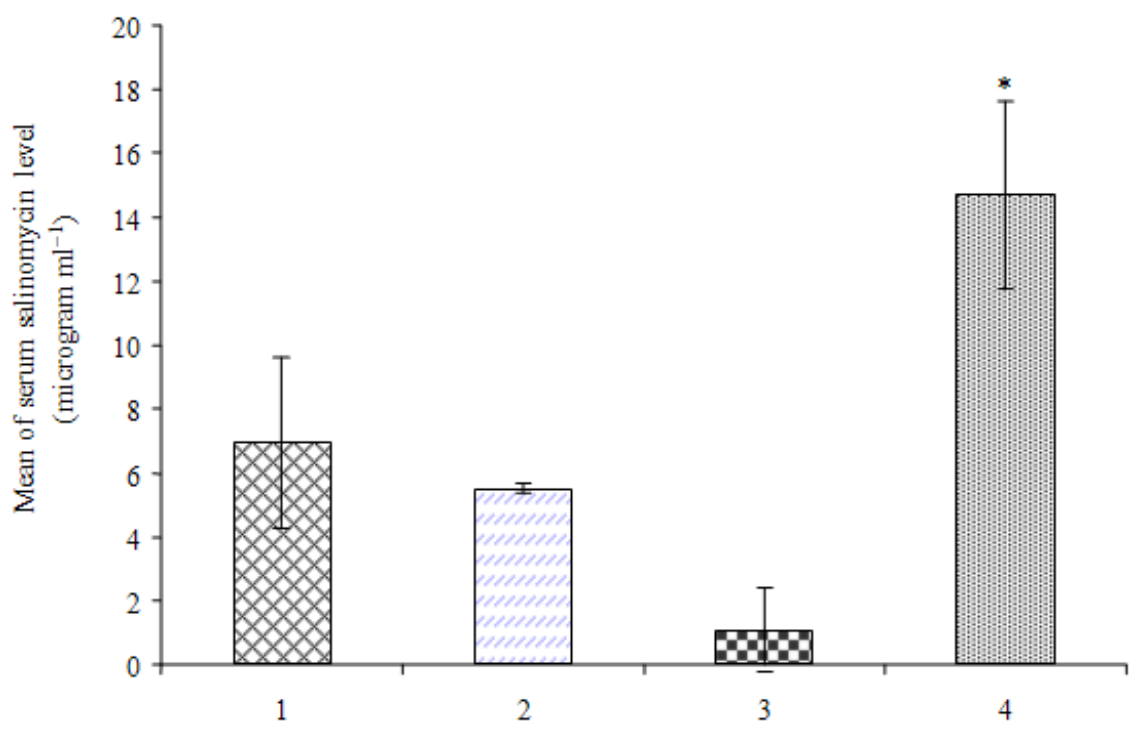

Fig. 1: Mean \pm S.E. serum concentration of salinomycin: 1: normal rats received salinomycin, 2: normal rats received salinomycin+ verapamil, 3: diabetic rats received salinomycin, 2: diabetic rats received salinomycin+ verapamil. $\mathrm{n}=8$, * represents significant difference between group4 and other groups $(\mathrm{p}<0.05)$

Two groups of rats received sterepozocin $\left(45 \mathrm{mg} \mathrm{kg}^{-1}\right.$ intravenously) for diabetes induction. One group of diabetic rats (those had blood glucose more than $600 \mathrm{mg}$ $\left.\mathrm{dl}^{-1}\right)$ received salinomycin $\left(1 \mathrm{mg} \mathrm{kg} \mathrm{kg}^{-1}\right.$ orally) and another group received verapamil $\left(25 \mathrm{mg} \mathrm{kg}^{-1}\right.$ orally) and $1 \mathrm{~h}$ later salinomycin $\left(1 \mathrm{mg} \mathrm{kg}^{-1}\right.$ orally). Serum concentration of salinomycin was measured by HPLC after $3 \mathrm{hrs}$ from its administration in all rats.

HPLC system was used from Shimadzu model (Japan) with column $\mathrm{C}_{18}$. Column temperature was set at $40 \mathrm{c}^{0}$. HPLC mobile phase A was water/acetonitrile (95:5, $\mathrm{v} / \mathrm{v}$ ), containing $0.1 \%$ formic acid; mobile phase B was acetonitrile containing $0.1 \%$ formic acid. The flow rate was $0.6 \mathrm{ml} \mathrm{min}$ and the injection volume was $20 \mathrm{ml}$.

\section{RESULTS}

Results show minimum level of salinomycin was detected in serum of diabetic rats. Although this level did not significantly differ with normal group. The serum concentration of salinomycin significantly was enhanced in diabetic rats which received verapamil together salinomycin; while this concentration did not significantly change in other groups. The mean of serum concentration of salinomycin ( \pm standard error) was illustrated at Fig. 1.

\section{DISCUSSION}

Our study shows the interaction salinomycin and verapamil changes in diabetic condition and increases serum level of salinomycin. It seems the some parts of this interaction are related to $\mathrm{p}$-gp transporting. P-gp function alters in diabetic status (Wu et al., 2009). Nawa et al. (2011) evaluated p-gp expression and function in diabetic rats. They demonstrated the expression and function of p-gp significantly decreased after 9 days induction of diabetes (Nawa et al., 2011). Also Liu et al. (2006) and Maeng et al. (2007) demonstrated the function of $\mathrm{p}$-gp decreased in the blood-brain barrier of streptozotocin-induced diabetic rats (Liu et al., 2006; Maeng et al., 2007). Insulin therapy restores impaired function and expression of Pgp in blood-brain barrier of experimental diabetes (Liu et al., 2008). But we did not demonstrate significant change at serum concentration of salinomycin in diabetic and normal rats. This may be related dieresis in diabetic rats and more excretion of salinomycin.

Salinomycin is a p-gp inhibitor (Riccioni et al., 2010). This drug inhibited p-gp in leukemic cells and increased cell death (Fuchs et al., 2010). In other hands, Verapamil is P-gp inhibitor (Bansal et al., 2009; De Klerk et al., 2010). Administration of verapamil enhanced uptake of dextromethorphan in the CNS of rats (Marier et al., 2005). We demonstrated coadministration of salinomycin and verapamil significantly increased serum level of salinomycin in diabetic rats. We think this enhancing may be related inhibition of salinomycin transport into kidney and CNS by verapamil and diabetic condition. But exact conclusion deeds more detailed studies. 


\section{CONCLUSION}

Since the p- glycoprotein activity decreases in diabetic conditions and verapamil inhibits it; probably transport of salinomycin from blood to tissues or its elimination was decreased that caused its elevated serum concentration.

\section{ACKNOWLEDGMENT}

The researchers wish to express their gratitude to the research council of Shahid Chamran University for their financial supports.

\section{REFERENCES}

Aller, S.G., J. Yu, A. Ward, Y. Weng and S. Chittaboina et al., 2009. Structure of Pglycoprotein reveals a molecular basis for polyspecific drug binding. Science, 323: 1718-1722. PMID: 19325113

Bansal, T., G. Mishra, M. Jaggi, R.K. Khar and S. Talegaonkar, 2009. Effect of P-glycoprotein inhibitor, verapamil, on oral bioavailability and pharmacokinetics of irinotecan in rats. Eur. J. Pharm. Sci., 36: 580-590. PMID: 19135530

De Klerk, O.L., A.T. Willemsen, F.J. Bosker, A.L. Bartels and N.H. Hendrikse et al., 2010. Regional increase in P-glycoprotein function in the bloodbrain barrier of patients with chronic schizophrenia: A PET study with [(11)C]verapamil as a probe for P-glycoprotein function. Psychiatry Res., 183: 151-156. PMID: 20620031

De Lange, E.C., 2004. Potential role of ABC transporters as a detoxification system at the bloodCSF barrier. Adv. Drug Deliv. Rev., 56: 17931809. PMID: 15381334

Fuchs, D., V. Daniel, M. Sadeghi, G. Opelz and C. Naujokat, 2010. Salinomycin overcomes ABC transporter-mediated multidrug and apoptosis resistance in human leukemia stem cell-like KG-1a cells. Biochem. Biophys. Res. Commun., 39: 10981104. PMID: 20350531

Hendrikse, N.H. and W. Vaalburg, 2002. Dynamics of multidrug resistance: P-glycoprotein analyses with positron emission tomography. Methods, 27: 228233. PMID: 12183111

Hsiao, P., T. Bui, R.J. Ho and J.D. Unadkat, 2008. In vitro-to-in vivo prediction of P-glycoprotein-based drug interactions at the human and rodent bloodbrain barrier. Drug Metab. Dispos., 36: 481-484. PMID: 18057117
Hsiao, P., L. Sasongko, J.M. Link, D.A. Mankoff and M. Muzi et al., 2006. Verapamil P-glycoprotein transport across the rat blood-brain barrier: Cyclosporine, a concentration inhibition analysis and comparison with human data. J. Pharmacol. Exp. Ther., 317: 704-710. PMID: 16415090

Lagas, J.S., R.W. Sparidans, R.A. van Waterschoot, E. Wagenaar and J.H. Beijnen et al., 2008. Pglycoprotein limits oral availability, brain penetration and toxicity of an anionic drug, the antibiotic salinomycin. Antimicrob Agents Chemother, 52: 1034-1039. PMID: 18195061

Liu, H., X. Liu, L. Jia, Y. Liu and H. Yang et al., 2008. Insulin therapy restores impaired function and expression of P-glycoprotein in blood-brain barrier of experimental diabetes. Biochem. Pharmacol., 75: 1649-1658. PMID: 18299117

Liu, H., X. Xu, Z. Yang, Y. Deng and X. Liu et al., 2006. Impaired function and expression of Pglycoprotein in blood-brain barrier of streptozotocin-induced diabetic rats. Brain Res., 1123: 245-252. PMID: 17074306

Maeng, H.J., M.H. Kim, H.E. Jin, S.M. Shin and T. Tsuruo et al., 2007. Functional induction of Pglycoprotein in the blood-brain barrier of streptozotocin-induced diabetic rats: Evidence for the involvement of nuclear factor-kappaB, a nitrosative stress-sensitive transcription factor, in the regulation. Drug Metab. Dispos., 35: 19962005. DOI: 10.1124/dmd.107.015800 PMID: 17664251

Marier, J.F., J.L. Deschenes, A. Hage, E. Seliniotakis and A. Gritsas et al., 2005. Enhancing the uptake of dextromethorphan in the CNS of rats by concomitant administration of the P-gp inhibitor verapamil. Life Sci., 77: 2911-2926. PMID: 15964599

Mercier, C., C. Masseguin, F. Roux, J. Gabrion and J.M. Scherrmann, 2004. Expression of Pglycoprotein (ABCB1) and Mrp1 (ABCC1) in adult rat brain: Focus on astrocytes. Brain Res., 1021: 32-40. PMID: 15328029

Nawa, A., W. Fujita-Hamabe and S. Tokuyama, 2011. Regulatory action of nitric oxide synthase on ileal p-glycoprotein expression under streptozotocininduced diabetic condition. Biol. Pharmcol. Bull., 34: 436-438. PMID: 21372399

Neuhaus, W., M. Stessl, E. Strizsik, B. Bennani-Baiti and M. Wirth et al., 2010. Blood-brain barrier cell line PBMEC/C1-2 possesses functionally active Pglycoprotein. Neurosci. Lett., 469: 224-228. PMID: 19963040 
Rajaian, H., J. Sadjedianfard, S. Nazifi and A.M. Kian, 2009. Drug Interaction between salinomycin and exogenous adrenaline in dogs. Am. J. Pharmacol. Toxicol., 4: 17-21. DOI: 10.3844/ajptsp.2009.17.21

Riccioni, R., M.L. Dupuis, M. Bernabei, E. Petrucci and L. Pasquini et al., 2010 . The cancer stem cell selective inhibitor salinomycin is a p-glycoprotein inhibitor. Blood Cells Mol. Dis., 45: 86-92. PMID: 20444629

Story, P. and A. Doube, 2004. A case of human poisoning by salinomycin, an agricultural antibiotic. N. Z. Med. J., 117: 799-799. PMID: 15107902
Sulova, Z., D. Macejova, M. Seres, J. Sedlak and J. Brtko et al., 2008. Combined treatment of P-gppositive L1210/VCR cells by verapamil and alltrans retinoic acid induces down-regulation of Pglycoprotein expression and transport activity. Toxicol. In Vitro, 22: 96-105. PMID: 17920233

Wu, K.C., H.J. Pan, H.S. Yin, M.R. Chen and S.C. Lu et al., 2009. Change in P-glycoprotein and caveolin protein expression in brain striatum capillaries in New Zealand Obese mice with type 2 diabetes. Life Sci., 85: 775-781. PMID: 19891976 